\title{
ANALISIS FAKTOR EKSTERNAL DAN PERFORMANCE INDIKATOR BPRS INDONESIA TERHADAP PEMBIAYAAN SEKTOR PERDAGANGAN, HOTEL DAN RESTORAN
}

\author{
Achmad Adhi Wiyono' ${ }^{1}$, Sri Mulatsih ${ }^{2}$ \\ ${ }^{1}$ Mahasiswa Program Magister Ilmu Ekonomi, FEM IPB \\ ${ }^{2}$ Staff Pengajar FEM IPB
}

\begin{abstract}
The trade, hotels and restaurants sector is one of the economic sectors that have an important role in the growth of the national economy. However, the development of trade, hotels and restaurants are still not optimal, is evidenced by the continued decline in the proportion of financing in this sector. The main problem of the trade, hotels and restaurants in Indonesia is limited access to capital and the regulatory capital faced by the microfinance sector, so that the necessary role of the banking sector one of them through the BPRS. The purpose of this study to analyze performance indicators and external factors affecting BPRS financing for trade, hotels and restaurants in Indonesia. This study uses a model of Vector Error Correction with monthly data from January 2011 to July 2016. The results showed that the BI rate, inflation, PaR and DPK significant effect on the financing of trade, hotels and restaurants, whereas no significant effect Leverage.
\end{abstract}

Keywords: BPRS, Financing, Performance, Trade hotel and restaurant.

\section{PENDAHULUAN}

Sektor perdagangan hotel dan restoran memiliki peran penting dalam meningkatkan perekonomian di Indonesia. Hal ini dibuktikan oleh kontribusi sektor PHR (Perdagangan Hotel dan Restoran) terhadap PDB (Produk Domestik Bruto) dan penyerapan tenaga kerja. Tahun 2014 subsektor perdagangan memiliki kontribusi sebesar $11.94 \%$ terhadap PDB atau sekitar 80\% dari total kontribusi terhadap PDB oleh sektor PHR.

Subsektor hotel dan restoran juga memiliki kontribusi penting dalam hal peningkatan devisa negara melalui perannya sebagai faktor penunjang untuk sektor pariwisata. Menurut data dari Kementrian Pariwisata (2016) jumlah wisatawan nasional tahun 2016 sebesar $7,908,534$ wisatawan meningkat di- bandingkan tahun 2011 yang hanya berjumlah 6,750,416 wisatawan. Namun jumlah wisatawan yang besar ini tidak diimbangi oleh kontribusi subsektor hotel dan restoran terhadap PDB. Menurut data dari BPS tahun 2015 tercatat sektor hotel dan restoran masing-masing hanya memberikan kontribusi sebesar $0.48 \%$ dan $2.34 \%$ terhadap penerimaan PDB.

Hal ini mengindikasikan kurang optimalnya pengelolaan dan kontribusi pemerintah terhadap sektor ini. Permasalahan juga dialami oleh subsektor perdagangan dimana laju pertumbuhan PDB sangat lambat dan mengalami tren penurunan, konsistensi penurunan terjadi pada tahun 2011 sampai tahun 2014. Laju Pertumbuhan PDB untuk masing-masing subsektor PHR ditunjukan oleh Tabel 1. 
Tabel 1 Laju Pertumbuhan PDB Sektor Perdagangan, Hotel dan Restoran

\begin{tabular}{lrrrrr}
\hline \multirow{2}{*}{ Subsektor perdagangan } & \multicolumn{5}{c}{ Laju pertumbuhan $(\%)$} \\
\cline { 2 - 6 } & 2010 & 2011 & 2012 & 2013 & 2014 \\
\hline Perdagangan & 9,70 & 10,01 & 8,68 & 5,84 & 4,42 \\
Hotel & 6,78 & 10,09 & 9,56 & 8,91 & 8,15 \\
Restoran & 3,31 & 4,16 & 4,22 & 5,24 & 4,96 \\
Total & 8,69 & 9,24 & 8,16 & 5,89 & 4,64 \\
\hline
\end{tabular}

Sumber: Badan Pusat Statistik, 2015 (diolah)

Sektor Perdagangan, Hotel dan Restoran mempunyai pengaruh yang positif dan signifikan dalam peningkatan Produk Domestik Regional Bruto (PDRB) (Amiri et al.,2015). Sektor PHR khususnya skala mikro menengah berperan penting terhadap pertumbuhan ekonomi nasional. Sektor ekonomi di Indonesia secara faktual sebagian besar didukung oleh sektor usaha mikro, kecil, dan menengah (UMKM) (Kara 2013).

Usaha (mikro) kecil menengah di Indonesia merupakan bagian penting dari sistem perekonomian nasional karena berperan untuk mempercepat pemerataan pertumbuhan ekonomi melalui misi penyediaan lapangan usaha dan lapangan kerja, peningkatan pendapatan masyarakat dan ikut berperan dalam meningkatkan perolehan devisa serta memperkokoh struktur industri nasional (Anggraeni et al. 2013). Oleh sebab itu, maka diperlukan peran dari pemerintah untuk terus meningkatkan eksistensi dan kinerja sektor PHR melalui regulasi dan trade policy yang menciptakan kesejahteraan terutama bagi pelaku usaha kecil.

Sementara itu, peningkatan jumlah BPRS (Bank Perkreditan Rakyat Syariah) berdasarkan lokasi, peningkatan DPK yang dihimpun dan peningkatan total pembiayaan tidak diikuti oleh kenaikan proporsi pembiayaan terhadap sektor perdagangan, hotel dan restoran. Proporsi pembiayaan pada sektor perdagangan, hotel dan restoran terus mengalami tren penurunan secara konsisten pada kurun waktu 6 tahun terakhir, padahal proporsi pembiayaan secara agregat mengalami tren peningkatan pada tahun 2011 sampai Juli 2016.

Menurut data dari OJK nominal pembiayaan BPRS terhadap sektor ekonomi pada tahun 2011 sebesar Rp. 2.675.930,- dan terus mengalami peningkatan pada Juli 2016 mencapai Rp. 6.407.580,-. Tahun 2011 proporsi pembiayaan terhadap sektor perdagangan sebesar $37,61 \%$ dan terus mengalami tren penurunan. Pada tahun 2013 proporsi pembiayaan menurun menjadi $32,57 \%$ dan terus berlanjut hingga Juli 2016 yang mencapai 27,28\% .

Selain itu peningkatan jumlah DPK dan instansi BPRS juga tidak diikuti peningkatan terhadap proporsi pembiayaan terhadap sektor PHR. Tahun 2011 jumlah DPK yang dihimpun oleh BPRS sebesar Rp.2.095.333,- terus mengalami konsistensi kenaikan yang pada Juli 2016 mencapai Rp.5.281.377,-. Jumlah lokasi BPRS juga mengalami peningkatan. Di tahun 2011 jumlahnya hanya mencapai 155 unit di seluruh Indonesia dan mengalami peningkatan pada Juli 2016 mencapai 165 unit. Perkembangan jumlah BPRS di Indonesia ditunjukan oleh Tabel 2. 


\begin{tabular}{ccc}
$\begin{array}{c}\text { Tabel } 2 \\
\text { Indonesia } \\
\text { Tahun }\end{array}$ & Jumlah & $\begin{array}{c}\text { Pertumbuhan } \\
(\%)\end{array}$ \\
\hline 2011 & 155 & - \\
2012 & 158 & 1,94 \\
2013 & 163 & 3,16 \\
2014 & 163 & 0 \\
2015 & 163 & 0 \\
2016 & 165 & 1,2 \\
\hline
\end{tabular}

Buchori A et al (2003) melakukan penelitian untuk mengetahui kinerja BPRS di Indonesia dengan menggunakan aspek Performance Indikator. Sehingga berdasarkan permasalahan tersebut dana Buchori et al (2003) maka penelitian ini bertujuan untuk mengetahui faktor eksternal dan aspek Performance Indikator yang memengaruhi pembiayaan sektor PHR pada BPRS, mengetahui faktor yang memberikan kontribusi terhadap keragaman pembiayaan sektor PHR BPRS di Indonesia jika terjadi guncangan. Faktor-faktor yang diteliti yaitu faktor (inflasi, DPK dan BI rate) dan factor internal atau performance
Indikator (kualitas portofolio/Potrofolio at Risk dan kecukupan modal/Leverage).

\section{METODE PENELITIAN}

Penelitian ini menggunakan data sekunder yang berupa data deret waktu (time series) antara tahun 2011 sampai 2016. Sumber data dari OJK (laporan keuangan bulanan BPRS di Indonesia), Kementrian Pariwisata (jumlah wisatawan), Badan Pusat Statistik (data sensus ekonomi, statistik hotel dan akomodasi lainnya, statistik restoran dan rumah makan, kontribusi sektoral terhadap PDB dan penyerapan tenaga kerja, distribusi Persentase PDB, laju pertumbuhan PDB, Klasifikasi Baku Lapangan Usaha), jurnal, dan data lainnya yang relevan untuk mendukung penelitian ini.

Metode analisis menggunakan model Vector Autoregression (VAR) apabila data yang digunakan stasioner dan tidak ada kointegrasi, sedangkan apabila data yang digunakan stasioner dan ada kointegrasi maka digunakan metode Vector Error Correction Model (VECM) sebagai berikut:

$$
\left(\begin{array}{c}
\Delta \text { PPHR } \\
\Delta \text { DPK } \\
\Delta \text { BIRATE }^{\text {INFLASI }} \\
\Delta \text { PAR } \\
\Delta \text { LEVERAGE }
\end{array}\right)=\left(\begin{array}{c}
\alpha_{10} \\
\vdots \\
\alpha_{80}
\end{array}\right)+\left(\begin{array}{ccc}
\alpha_{11} & \cdots & \alpha_{18} \\
\vdots & \ddots & \vdots \\
\alpha_{81} & \cdots & \alpha_{88}
\end{array}\right)\left(\begin{array}{c}
\Delta \text { PPHR }_{t-1} \\
\Delta \mathrm{DPK}_{t-1} \\
\Delta \text { BIRATE }_{t-1} \\
\Delta \text { INFLASI }_{t-1} \\
\Delta \text { PAR }_{t-1} \\
\Delta \text { LEVERAGE }_{t-1}
\end{array}\right)+\left(\begin{array}{c}
e_{1 t} \\
\vdots \\
e_{8 t}
\end{array}\right)
$$

Keterangan:

$\begin{aligned} \text { PPHR }= & \text { Pembiayaan sektor } \\ & \text { perdagangan, hotel dan } \\ & \text { restoran pada BPRS } \\ & \text { periode ke-t (Juta Rupiah) } \\ = & \text { Tingkat inflasi periode } \\ & \text { ke-t }(\%)\end{aligned}$

BIRATE = Tingkat suku bunga Bank Indonesia periode ke-t (\%)

DPK = Jumlah dana pihak ketiga periode ke-t (\%)

$\mathrm{PaR}=$ Portofolio at Risk periode ke-t (\%) 
LEVERAGE $=$ Leverage periode ke-t $(\%)$

\section{HASIL DAN PEMBAHASAN}

\section{Gambaran Umum Pembiayaan pada BPRS di Indonesia}

Keberadaan bank syariah di Indonesia telah diakui secara legal dengan diberlakukannya. Undangundang No 7 tahun 1992 sebagaimana telah diamandemen dengan Undangundang No 10 tahun 1998 tentang Perbankan. Menurut Undang-Undang Nomor 21 tahun 2008 pasal 19 ayat 1 tentang Perbankan Syariah, fungsi dan kegiatan bank syariah adalah menghimpun dana dan menyalurkan dana yang disebut sebagai pembiayaan.

Terdapatnya BPRS pada bank syariah di Indonesia memiliki tujuan untuk melayani masyarakat ekonomi lemah dan pengusaha kecil baik di perdesaan maupun diperkotaan yang umumnya tidak dapat dijangkau oleh bank umum. Karakteristik BPRS memiliki kemiripan dengan Lembaga Keuangan Mikro. Para ahli Lembaga Keuangan Mikro telah mengungkapkan kerangka penilaian kinerja bagi LKM melalui penggunaan metode Performance Indikator (PI). Menurut Supriyadi (2013) pembiayaan pada Bank berbeda-beda sesuai dengan kategori masing-masing. Baitul Mal Wat-Tamwil (BMT) besarnya antara Rp. 1000.000,sampai Rp. 5.000.000,- jangka waktu minimal setengah tahun dan maksimal lima tahun, Bank Perkreditan Rakyat Syariah (BPRS) pembiayaannya sebesar Rp. 5.000.000,- sampai Rp. 50.000.000,jangka waktu minimal 1 tahun dan maksimal diserahkan kepada kebijakan pihak Bank.

Menurut data statistik perbankan syariah yang terdapat dalam website Otoritas Jasa Keuangan, pembiayaan yang dikeluarkan BPRS relatif mengalami peningkatan dari tahun 2011 hingga Juli 2016. Tahun 2011 total pembiayaan yang dikeluarkan BPRS sebesar 2675 miliar rupiah, mengalami peningkatan hingga akhir Juli 2016 menjadi 6407 miliar rupiah. Pembiayaan tersebut disalurkan ke dalam berbagai sektor ekonomi termasuk sektor perdagangan, hotel dan restoran. Gambar 4 menunjukkan perkembangan pembiayaan yang dikeluarkan BPRS dari tahun 2011 hingga Juli 2016.

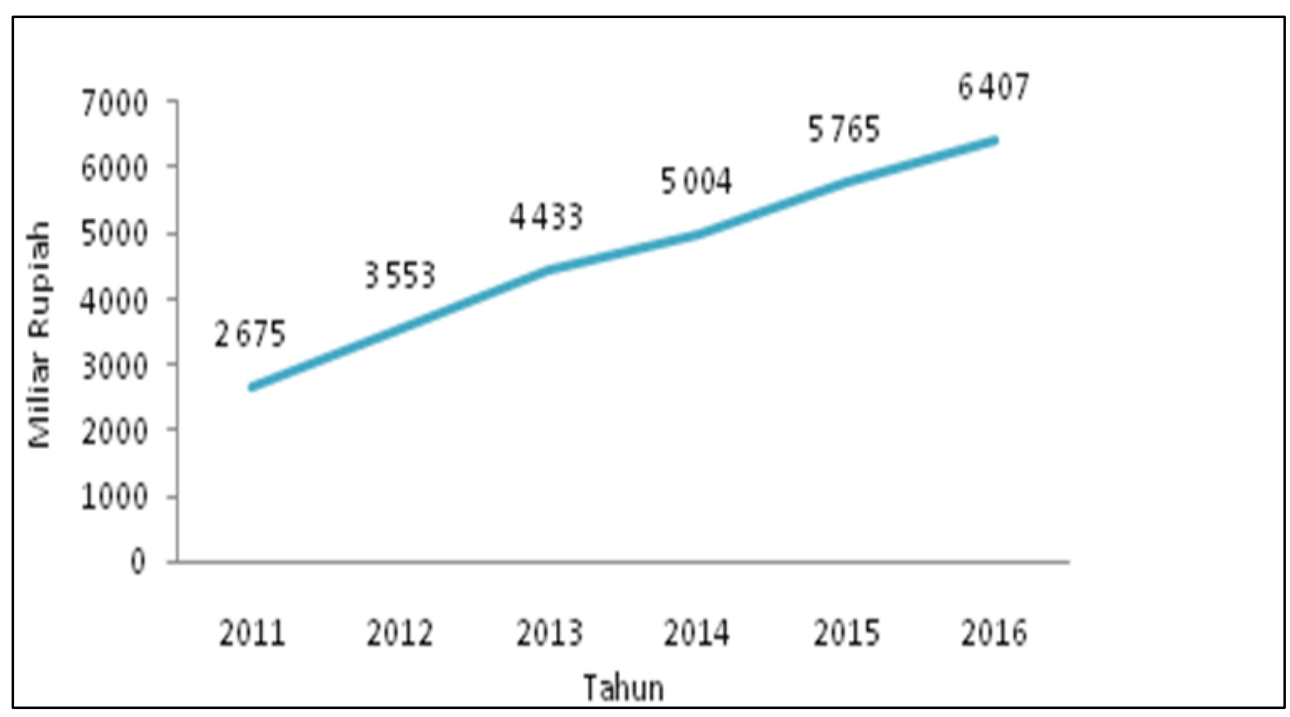

Sumber: Statistik Perbankan Syariah, 2016 (diolah)

Gambar 4 Perkembangan pembiayaan BPRS di Indonesia 
Perkembangan Pembiayaan Sektor Perdagangan Hotel dan Restoran BPRS

Pembiayaan BPRS pada tahun 2015 di sektor PHR (Pembiayaan terhadap sektor perdagangan, hotel dan restoran) cukup besar, mencapai Rp1.7 trilyun. Hal ini mengindikasikan bahwa terdapat banyak aktivitas ekonomi rill yang tergerak dalam sektor ini. Tahun
2011, total pembiayaan untuk sektor perdagangan, hotel dan restoran sebesar Rp1 triliun atau sekitar 37,61\% dari total pembiayaan BPRS. Selanjutnya, pada tahun 2012 mengalami peningkatan menjadi Rp1,2 triliun dan di tahun 2013 sebesar Rp1,4 triliun. Pada 2016 pembiayaan terhadap sektor PHR sebesar (januari-Juli) sebesar Rp1,7 triliun. Gambar 5 menunjukkan perkembangan pembiayaan PHR.

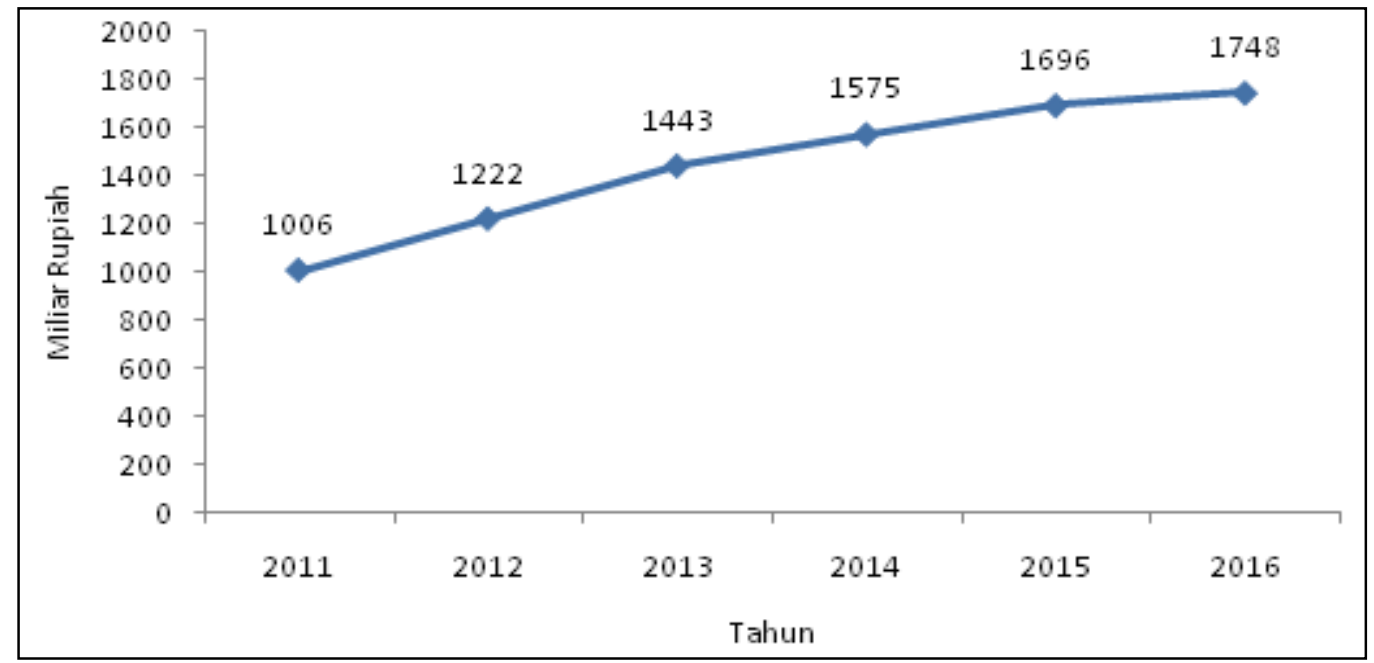

Sumber: Statistik Perbankan Syariah, 2016 (diolah)

Gambar 5 Perkembangan pembiayaan sektor PHR pada BPRS di Indonesia

\section{Perkembangan Tingkat Inflasi}

Tingkat inflasi di Indonesia mengalami fluktuasi dalam kurun waktu 2011 hingga Juli 2016. Tingkat inflasi bulan Desember 2011 sebesar 3,79\%. Nilai inflasi tersebut mengalami penurunan signifikan dibanding awal tahun, dimana inflasi mencapai 7,02\%. Desember 2012 tingkat inflasi sebesar $4,30 \%$, mengalami kenaikan dibanding tahun 2011, lalu pada Desember 2014 tingkat inflasi sebesar $8,36 \%$,dimana pada tahun 2014 tingkat inflasi mengalami kenaikan yang cukup signifikan. Juli 2016 tingkat inflasi mengalami penurunan menjadi $3,21 \%$ yang merupakan indikasi keadaan ekonomi mulai membaik. Gambar 6 menunjukkan perkembangan inflasi dari Januari 2011 hingga Juli 2016. 


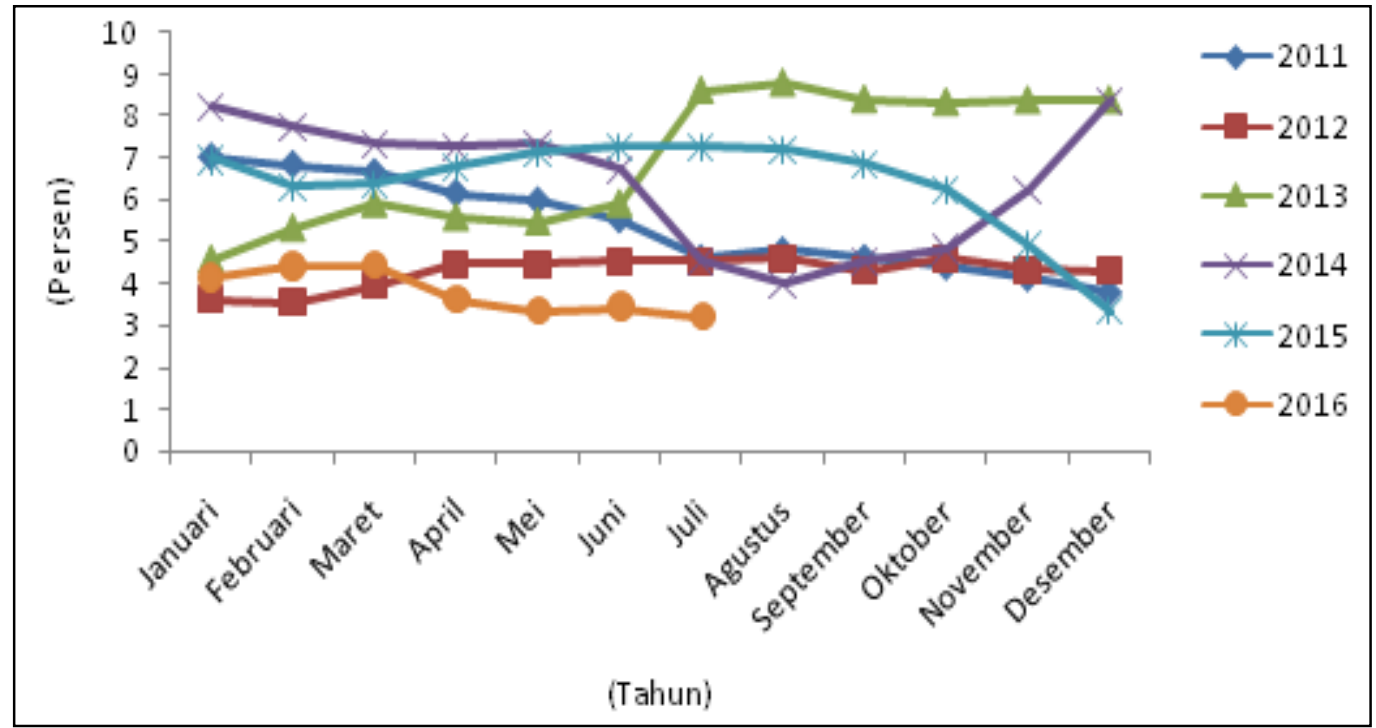

Sumber: Bank Sentral Indonesia, 2016 (diolah)

Gambar 6 Perkembangan Tingkat Inflasi

\section{Perkembangan BI Rate}

$\mathrm{BI}$ rate merupakan salah satu kebijakan yang mencerminkan sikap atau stance kebijakan moneter yang ditetapkan oleh Bank Indonesia dan diumumkan ke publik. Kenaikan BI rate berbanding lurus dengan kenaikan suku bunga kredit yang akan ditetapkan oleh bank konvensional. $\mathrm{BI}$ rate adalah pembayaran bunga tahunan dikarenakan suatu pinjaman dalam bentuk presentase dari pinjaman yang diperoleh dari jumlah bunga yang diterima tiap tahun dibagi dengan jumlah pinjaman. Kenaikan suku bunga kredit bank konvensional berbanding terbalik terhadap permintaan kredit. Gambar 7 menunjukkan perkembangan BI rate dari tahun 2011 hingga Juli 2016.

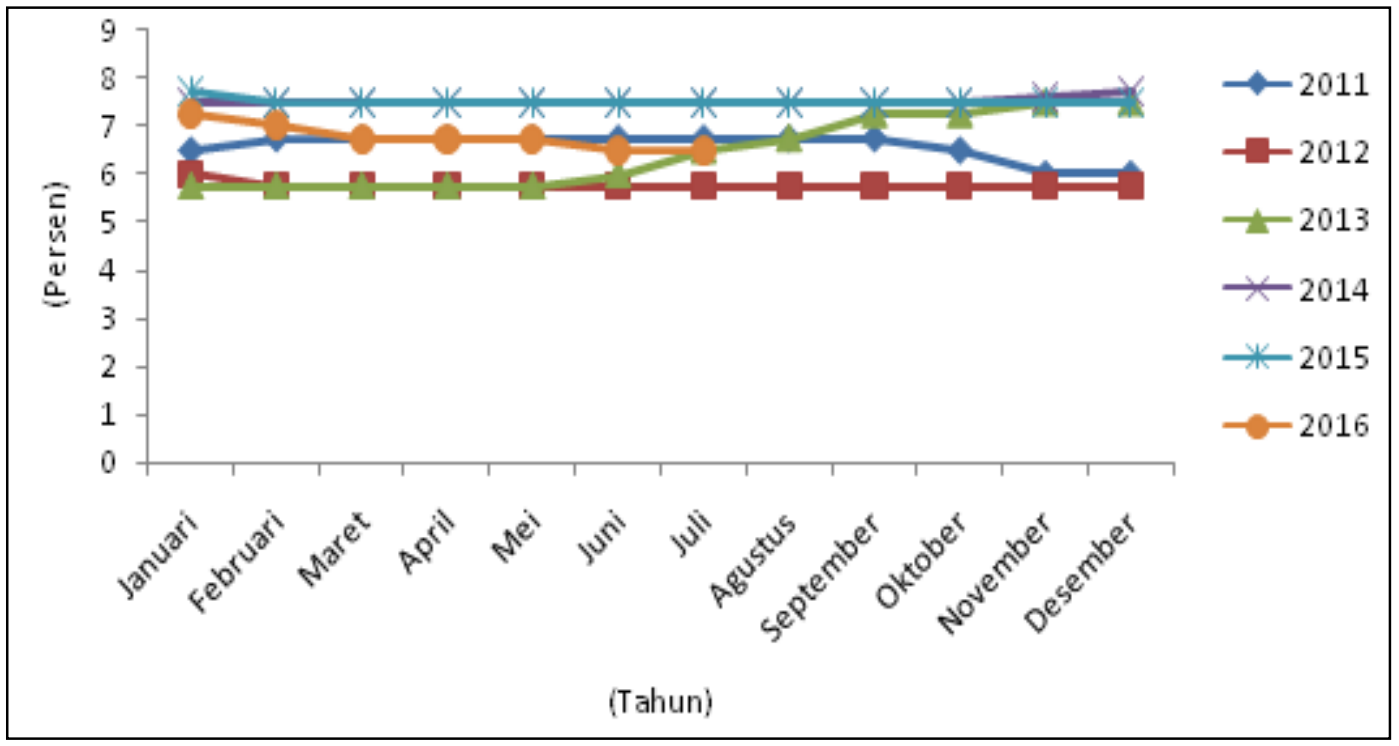

Sumber: Bank Sentral Indonesia, 2016 (diolah)

Gambar 7 Perkembangan BI Rate 


\section{Perkembangan Jumlah Dana Pihak Ketiga (DPK) BPRS}

Menurut Peraturan Bank Indonesia No 10/19/PBI/2008, Dana Pihak Ketiga adalah kewajiban bank kepada penduduk dalam rupiah dan valuta asing. Dana Pihak Ketiga yang dihimpun oleh BPRS di Indonesia jika dikumulatifkan jumlahnya pada tahun 2011 sebesar 2095 miliar rupiah. Dana Pihak Ketiga yang dihimpun terus mengalami konsistensi peningkatan. Tahun 2015 jumlah DPK yang dihimpun sebesar 4,801 miliar rupiah dan mengalami peningkatan pada Juli 2016 menjadi sebesar 5,281 miliar rupiah. Gambar 8 menjelaskan perkembangan jumlah DPK yang dihimpun oleh BPRS di Indonesia.

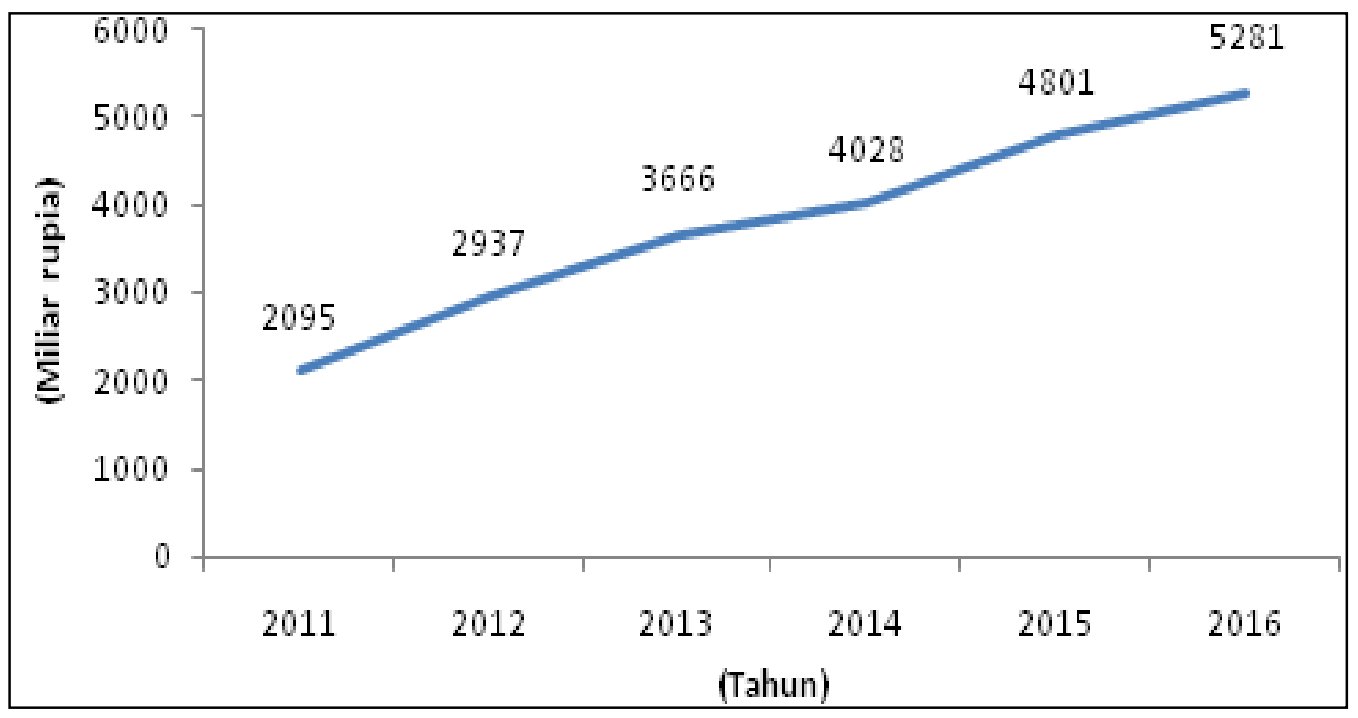

Sumber: Statistik Perbankan Syariah, 2016 (diolah)

Gambar 8 Perkembangan DPK pada BPRS di Indonesia

\section{Perkembangan Portolio at Risk (PaR) pada BPRS}

Rasio PaR yang semakin menurun dari tahun ke tahun menunjukkan bahwa BPRS tersebut menuju ke arah yang lebih baik. Sebaliknya jika rasio PaR semakin meningkat maka hal ini menunjukkan bahwa BPRS tersebut mengalami masalah delinquency yang cukup serius. Selain itu, rasio $\mathrm{PaR}$ dipengaruhi oleh kebijakan penghapusbukuan suatu BPRS. Jika ada pembiayaan yang sepertinya tidak akan dibayar namun tidak dihapusbukukan oleh BPRS maka rasio PaR BPRS tersebut akan lebih tinggi dibandingkan jika BPRS tersebut menghapusbukukan pembiayaan itu.
Namun jika penghapusbukuan pembiayaan dilakukan dengan tergesagesa maka rasio PaR terlihat rendah dan BPRS tersebut dinilai cukup baik. Oleh karena itu harus dilihat pula nilai PPAP di neraca. Bila nilai PPAP cukup besar untuk menghapusbukukan pembiayaan maka hal ini mencerminkan biaya yang tinggi untuk pembiayaan yang dihapusbukukan.

Berdasarkan Gambar 9 dapat dilihat bahwa perkembangan nilai $\mathrm{PaR}$ selama kurun waktu 2011 hingga Juli 2016 cenderung fluktuatif. Namun di akhir tahun 2015 hingga pertengahan tahun 2016 presentase PaR cenderung meningkat dan tinggi mencapai lebih dari 9\%. Tingkat PaR yang dimiliki BPRS tersebut berada di atas rentang 
standar yang ditetapkan oleh Bank Indonesia bahwa batas wajar rasio PaR sebesar 5\%. Banyaknya pembiayaan bermasalah akan berdampak pada menurunnya tingkat kepercayaan masyarakat terhadap kinerja BPRS. Oleh karena itu, diperlukan usaha dari BPRS untuk mengendalikan pembiayaan bermasalah salah satunya dengan cara meningkatkan kualitas pembiayaan.

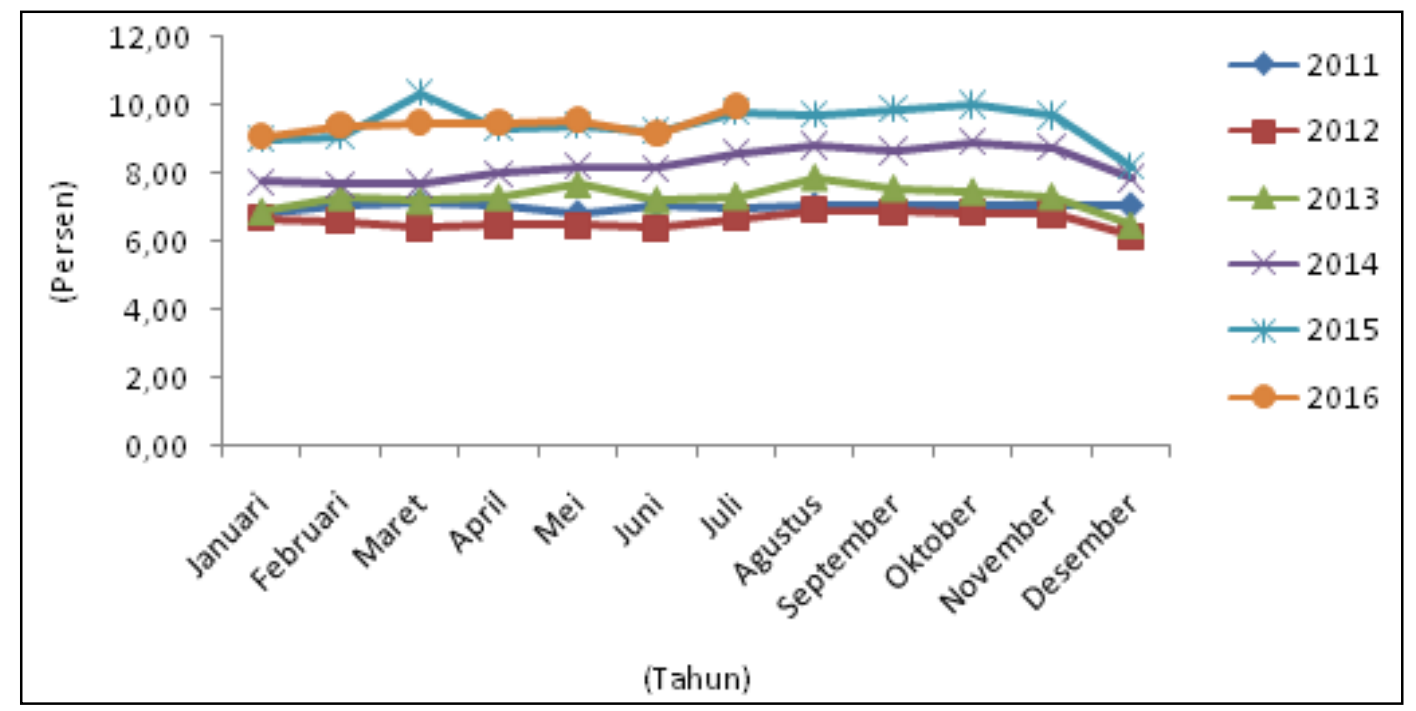

Sumber: Statistik Perbankan Syariah, 2016 (diolah)

Gambar 9 Perkembangan PaR pada BPRS di Indonesia

\section{Perkembangan Leverage pada BPRS}

Leverage adalah membandingkan antara kewajiban kepada pihak ketiga dengan modal. Mengingat modal adalah terbatas maka BPRS berusaha untuk meningkatkan sumber-sumber dana dari luar dan pada akhirnya akan dapat meningkatkan pendapatan. Pada umumnya jika Leverage meningkat dari tahun ke tahun maka ROE-nya juga akan meningkat. Tetapi jika OC dan PPAP/PYD lebih besar dari 15\% maka disarankan untuk tidak meningkatkan liabilities. Hal ini disebabkan karena untuk meningkatkan liabilities harus dipertimbangkan pula kemampuan untuk membayar kembali. Pada kurun waktu antara 2011 sampai Juli 2016, tingkat Leverage cenderung fluktuatif dan tidak terlalu mengalami perubahan secara signifikan. Desember 2011 tingkat Leverage sebesar 1,24\%. Sedangkan pada Desember 2013 leverage meningkat menjadi $1,28 \%$ dan mengalami penurunan pada Desember 2014 menjadi 1,27\%. Bulan Juli 2016 presentase Leverage meningkat dan menyentuh angka $1,33 \%$. Gambar 10 menunjukkan perkembangan Leverage BPRS $\mathrm{di}$ Indonesia. 


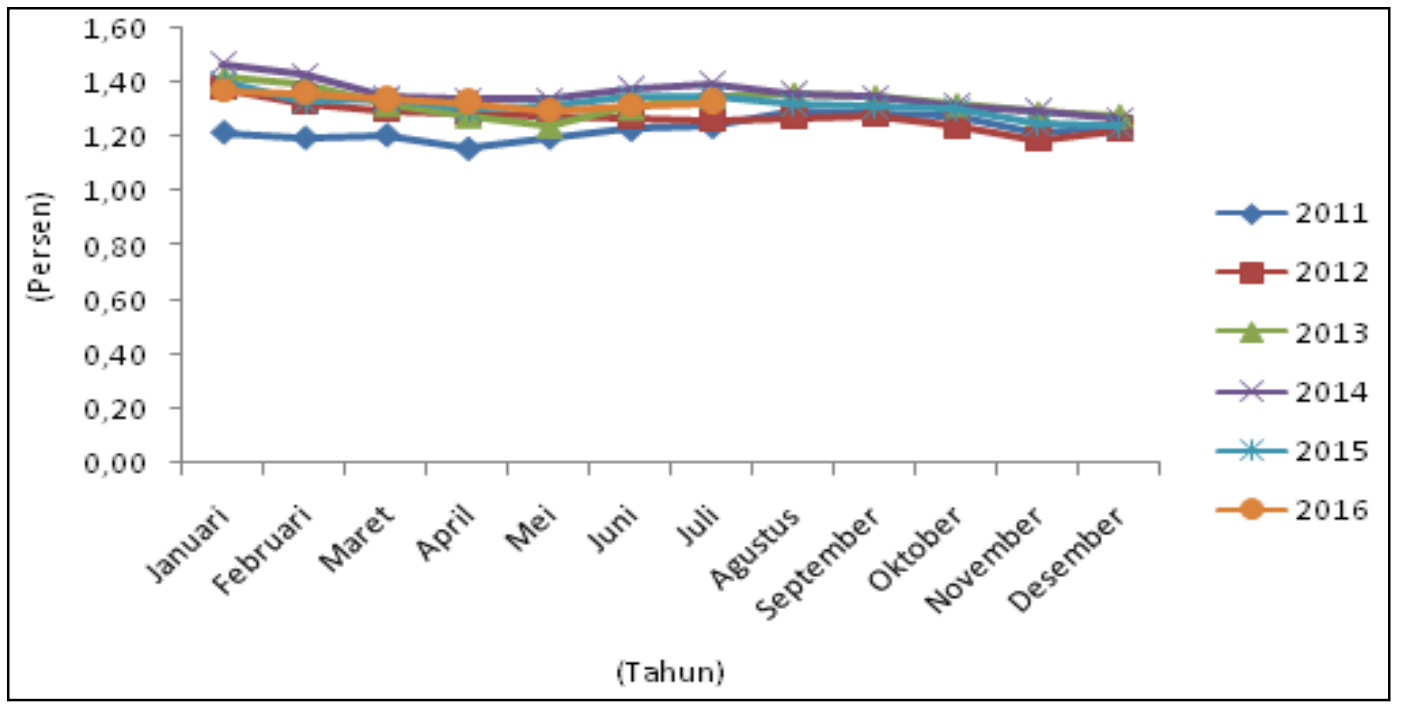

Sumber: Statistik Perbankan Syariah, 2016 (diolah)

Gambar 10 Perkembangan Leverage BPRS di Indonesia

Tabel 3 Hasil Estimasi VECM pada Jangka Pendek dan Jangka Panjang

\begin{tabular}{lrc}
\hline \multicolumn{1}{c}{ Variabel } & Koefisien & $\mid$ t-statistik \\
\hline CointEq1 & Jangka Pendek & \\
D(LPEMBIAYAAN(-1)) & $-0,1504$ & 1,6123 \\
D(LLEVERAGE(-1)) & 0,2203 & 1,7837 \\
D(LINFLASI (-1)) & 0,4369 & 1,9534 \\
D(BIRATE(-1)) & 0,0353 & 0,5553 \\
D(DPK(-1)) & $-0,07004$ & 0,1974 \\
D(PaR(-1)) & $-0,3121^{*}$ & 1,9862 \\
\hline & $-0,1987$ & 1,0712 \\
D(LLEVERAGE(-1)) & Jangka Panjang & \\
D(LINFLASI (-1)) & 2,5984 & 0,3379 \\
D(BIRATE(-1)) & $0,1334^{*}$ & 2,2679 \\
D(DPK(-1)) & $-0,3803 *$ & 2,0693 \\
D(PaR(-1)) & $0,5985^{*}$ & 8,9068 \\
C & $0,3523 *$ & 2,0218 \\
*signifikan pada taraf nyata 5\% & $-9,7354$ & -
\end{tabular}

\section{Hasil Estimasi Vector Error Correction Model (VECM)}

Tujuan Uji Estimasi VECM adalah untuk menunjukkan kombinasi hubungan variabel pada jangka pendek dan jangka panjang. Pada jangka pendek, variabel yang memengaruhi pembiayaan PHR BPRS di Indonesia secara signifikan adalah DPK. Variabel DPK signifikan memengaruhi pembiayaan PHR secara positif pada lag 1.
Sedangkan pada jangka panjang, variabel yang secara signifikan memengaruhi pembiayaan PHR adalah BI rate, DPK, Inflasi dan PaR. Jadi DPK mempengaruhi besarnya pembiayaan sektor PHR dalam jangka pendek dan jangka panjang. Variabel yang tidak berpengaruh signifikan pada jangka pendek maupun jangka panjang adalah Leverage. Koreksi kesalahan dalam penelitian ini sebesar $0,1504 \%$, dapat 
diartikan terdapat penyesuaian dari persamaan jangka pendek menuju persamaan jangka panjangnya sebesar 0,1504\%. Hasil Uji Estimasi VECM ditunjukan oleh Tabel 3.

\section{Analisis Impulse Respon Function (IRF)}

Analisis IRF dapat digunakan untuk melihat dampak dari salah satu shock terhadap shock lainnya pada saat sekarang dan pada masa yang akan datang dari variabel endogen.

\section{Respon Pembiayaan Sektor PHR terhadap Guncangan BI rate}

Pembiayaan PHR belum merespon guncangan $\mathrm{BI}$ rate sebesar satu standar deviasi pada bulan pertama. Guncangan yang terjadi pada BI rate sebesar satu standar deviasi mulai direspon negatif oleh pembiayaan PHR pada bulan ketiga hingga bulan ke 50. Pada periode ini, guncangan $\mathrm{BI}$ rate mengakibatkan penurunan pembiayaan perdagangan, hotel dan restoran antara 0,04\% hingga $0,034 \%$. Hingga bulan ke 50 pembiayaan belum mencapai kestabilan. Hubungan negatif antara BI rate dan pembiayaan PHR ini sesuai dengan hipotesis awal, dimana guncangan $\mathrm{BI}$ rate akan menurunkan pembiayaan PHR. Hubungan antara $\mathrm{BI}$ rate dan pembiayaan PHR BPRS memiliki hubungan yang tidak langsung, BI rate akan memengaruhi suku bunga kredit dan permintaan kredit bank konvensional terlebih dahulu kemudian baru memengaruhi pembiayaan PHR BPRS. Gambar 11 menunjukkan respon pembiayaan sektor PHR terhadap guncangan $\mathrm{BI}$ rate.

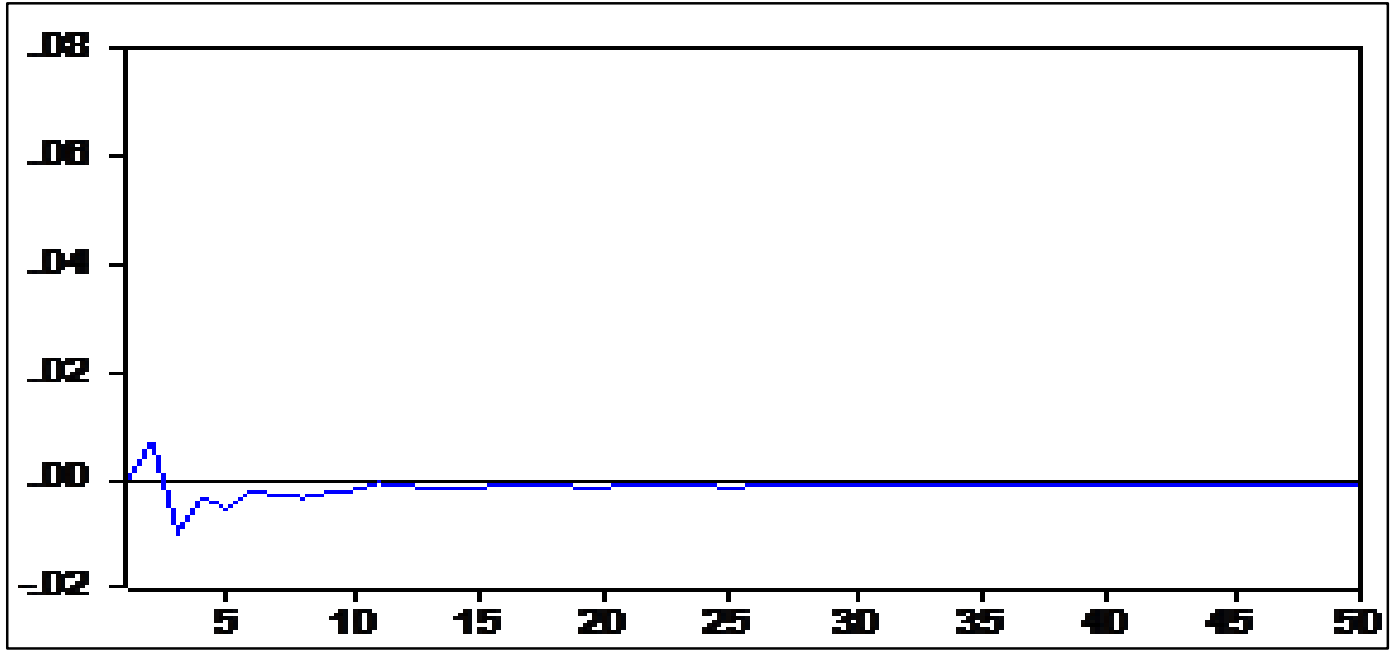

Gambar 11 Respon pembiayaan sektor PHR terhadap guncangan BI rate

\section{Respon Pembiayaan Sektor PHR terhadap Guncangan Inflasi}

Guncangan Inflasi sebesar satu standar deviasi belum direspon oleh pembiayaan PHR pada bulan pertama. Respon pembiayaan PHR terhadap guncangan Inflasi sebesar satu standar deviasi mulai direspon negatif dan mengalami fluktuasi pada bulan kedua hingga bulan ke 50 dan berpengaruh terhadap penurunan pembiayaan PHR sebesar 0,04 hingga 0,039. Hubungan negatif antara Inflasi dan pembiayaan PHR ini sesuai dengan hipotesis awal, di mana guncangan Inflasi akan menurunkan pembiayaan PHR. Gambar 12 menunjukkan respon pembiayaan sektor PHR terhadap guncangan Inflasi. 


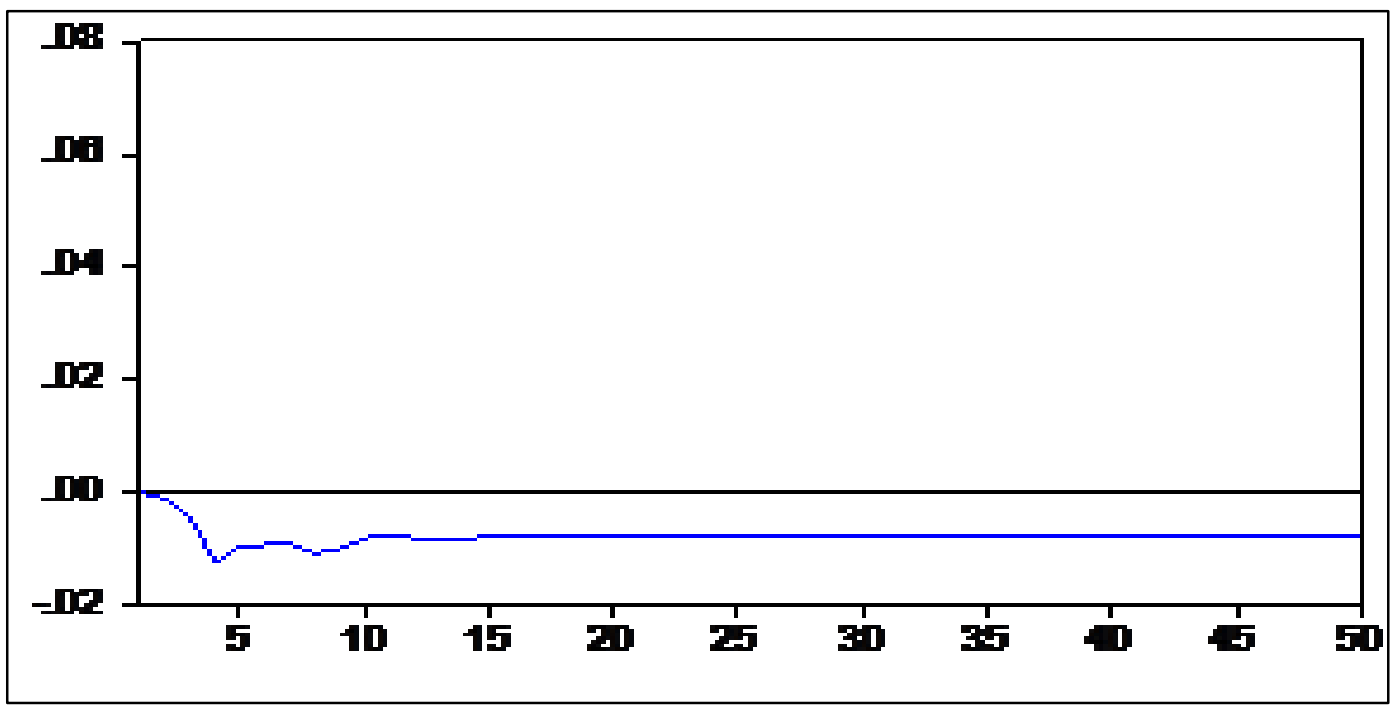

Gambar 12 Respon Pembiayaan Sektor PHR terhadap Guncangan Inflasi

\section{Respon Pembiayaan Sektor PHR terhadap Guncangan DPK}

Guncangan DPK sebesar satu standar deviasi belum direspon oleh pembiayaan PHR pada bulan pertama. Respon pembiayaan PHR terhadap guncangan DPK sebesar satu standar deviasi mulai direspon positif dan mengalami fluktuasi pada bulan kedua hingga bulan ke 50. Pada periode ini, guncangan DPK mengakibatkan peningkatan pembiayaan PHR antara
0,039\% hingga $0,04 \%$. Hubungan positif antara DPK dengan pembiayaan PHR sesuai dengan hipotesis awal dan juga sesuai dengan data yang diperoleh bahwa peningkatan jumlah DPK BPRS diiringi dengan peningkatan jumlah pembiayaan sektor PHR secara nominal. Penurunan jumlah DPK juga akan berdampak pada menurunnya pembiayaan sektor PHR. Gambar 13 menunjukkan Respon pembiayaan sektor PHR terhadap guncangan DPK

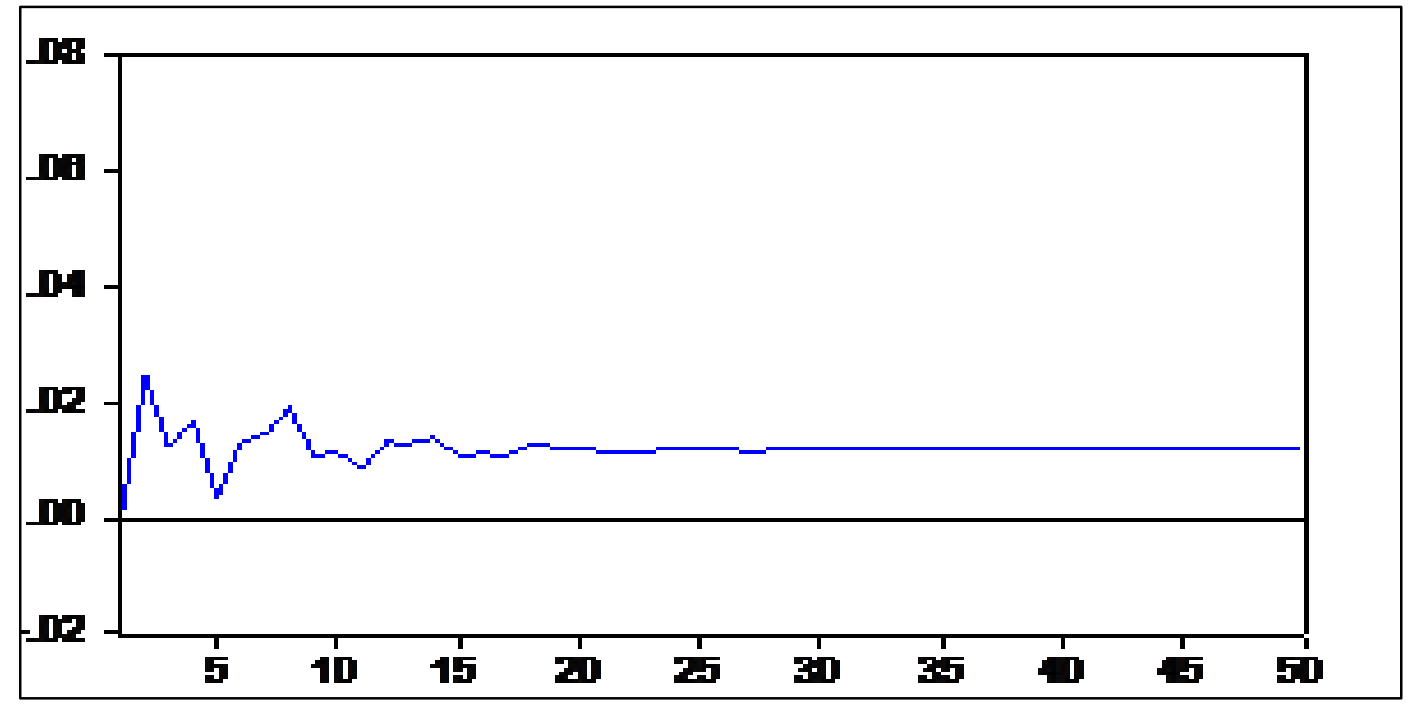

Gambar 13 Respon Pembiayaan Sektor PHR terhadap Guncangan DPK 


\section{Respon Pembiayaan Sektor PHR terhadap Guncangan PaR}

Guncangan PaR sebesar satu standar deviasi belum direspon oleh pembiayaan PHR pada bulan pertama. Respon pembiayaan PHR terhadap guncangan $\mathrm{PaR}$ sebesar satu standar deviasi mulai direspon positif dan mengalami fluktuasi pada bulan kedua hingga bulan ke 50 kecuali pada bulan kelima guncangan PaR direspon negatif. Pada periode ini, guncangan $\mathrm{PaR}$ mengakibatkan peningkatan pembiayaan PHR antara 0,39\% hingga 0,04\%. Peningkatan jumlah $\mathrm{PaR}$ dikarenakan adanya kemungkinan perusahaan yang mengalami pembiayaan bermasalah justru semakin diberikan anggaran pembiayaan lebih guna memperbaiki kondisi keuangan instansi tersebut dengan harapan diperoleh feedback guna mengurangi resiko dari PaR yang ada. Gambar 14 Respon pembiayaan sektor PHR terhadap guncangan PaR.

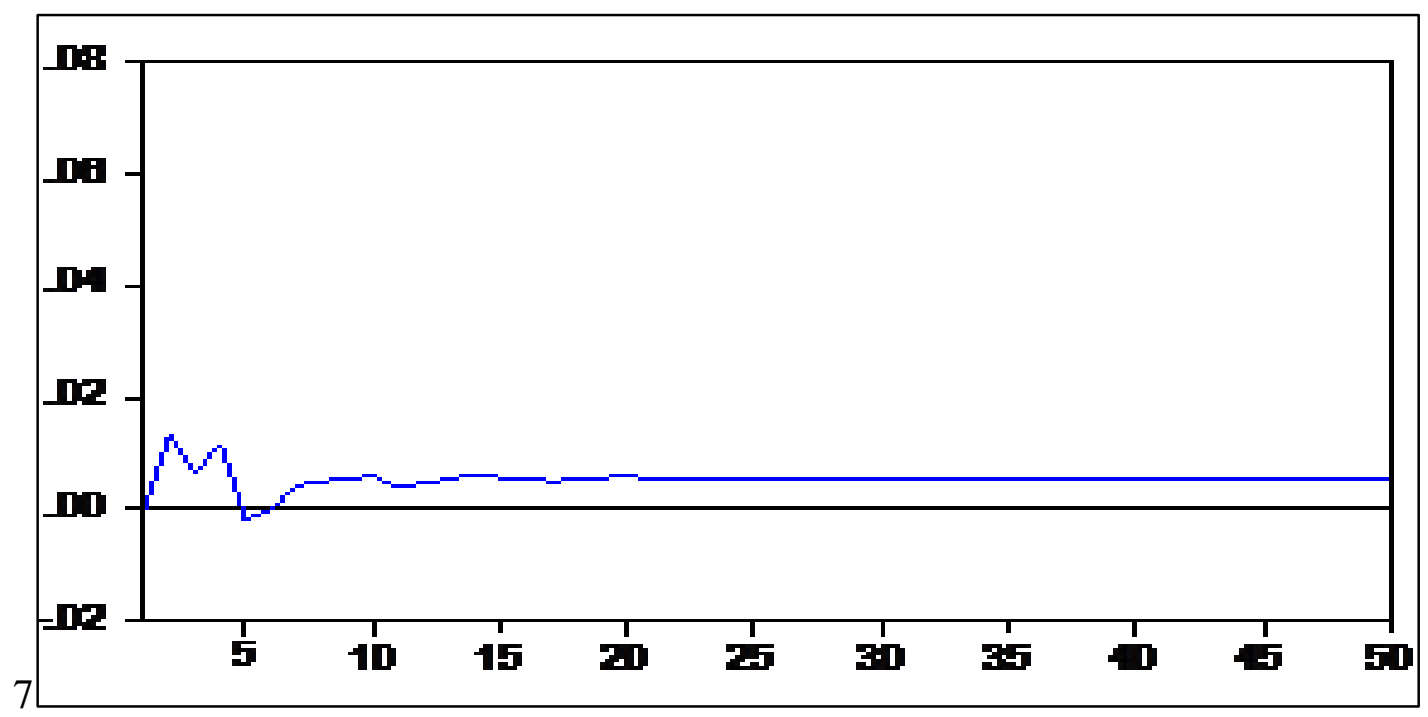

Gambar 14 Respon Pembiayaan Sektor PHR terhadap Guncangan PaR

Rasio PaR yang semakin menurun dari tahun ke tahun menunjukkan bahwa BPRS tersebut menuju ke arah yang lebih baik. Sebaliknya jika rasio PaR semakin meningkat dari tahun ke tahun maka hal ini menunjukkan bahwa BPRS tersebut mengalami masalah delinquency yang cukup serius. Hubungan positif antara pembiayaan PHR dan variabel PaR sesuai dengan penelitian yang dilakukan oleh Buchari et al (2003).

\section{Respon Pembiayaan Sektor PHR terhadap Guncangan Leverage}

Guncangan Leverage sebesar satu standar deviasi belum direspon oleh pembiayaan PHR pada bulan pertama. Respon pembiayaan PHR terhadap guncangan Leverage sebesar satu standar deviasi mulai direspon positif dan mengalami fluktuasi pada bulan kedua hingga bulan ke 50. Pada periode ini, guncangan Leverage mengakibatkan peningkatan pembiayaan PHR antara $0,04 \%$ hingga $0,039 \%$. Hubungan positif antara Leverage dengan pembiayaan PHR sesuai dengan hipotesis awal dan juga sesuai dengan data yang diperoleh bahwa peningkatan jumlah Leverage BPRS diiringi dengan peningkatan jumlah pembiayaan sektor PHR secara nominal. Penurunan jumlah Leverage 
juga akan berdampak pada menurunnya pembiayaan sektor PHR. Gambar 15
Respon pembiayaan sektor PHR terhadap guncangan Leverage.

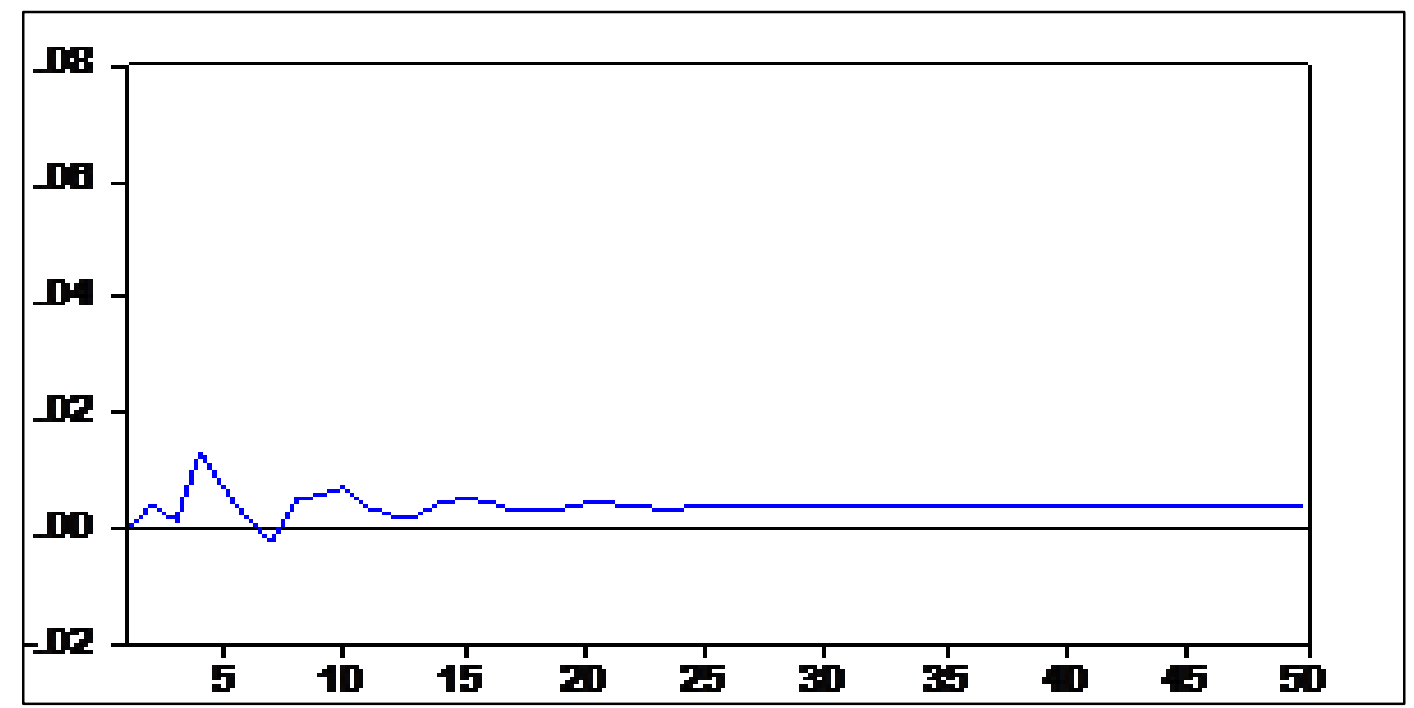

Gambar 15 Respon Pembiayaan Sektor PHR terhadap Guncangan Leverage

Hubungan positif disebabkan oleh modal BPRS yang terbatas, maka BPRS berusaha meningkatkan sumber dana dari luar untuk meningkatkan pemasukan yang selanjutnya akan berdampak pada meningkatnya alokasikan pembiayaan yang diberikan kepada nasabah. Pada umumnya jika Leverage meningkat dari tahun ke tahun maka ROE-nya juga akan meningkat. Tetapi jika Pembiayaan yang diberikan lebih besar dari $15 \%$ maka disarankan untuk tidak meningkatkan sliabilities. Hal ini disebabkan karena untuk meningkatkan liabilities harus dipertimbangkan pula kemampuan untuk membayar kembali.

\section{Analisis Forecasting Error Variance Decomposition (FEVD)}

Berdasarkan hasil analisis Variance Decomposition dari uji yang dilakukan menunjukkan bahwa pada bulan pertama, keragaman fluktuasi pembiayaan PHR didominasi oleh guncangan pembiayaan PHR itu sendiri, yakni sebesar $100 \%$ dan terus berlanjut hingga periode akhir (bulan ke-50) dengan proporsi yang terus menurun yakni sebesar 26,8\%. Keragaman mulai terlihat pada bulan kedua, di mana variabel-variabel lain mulai memengaruhi keragaman pembiayaan PHR. Gambar 16 menunjukkan hasil Uji FEVD. 


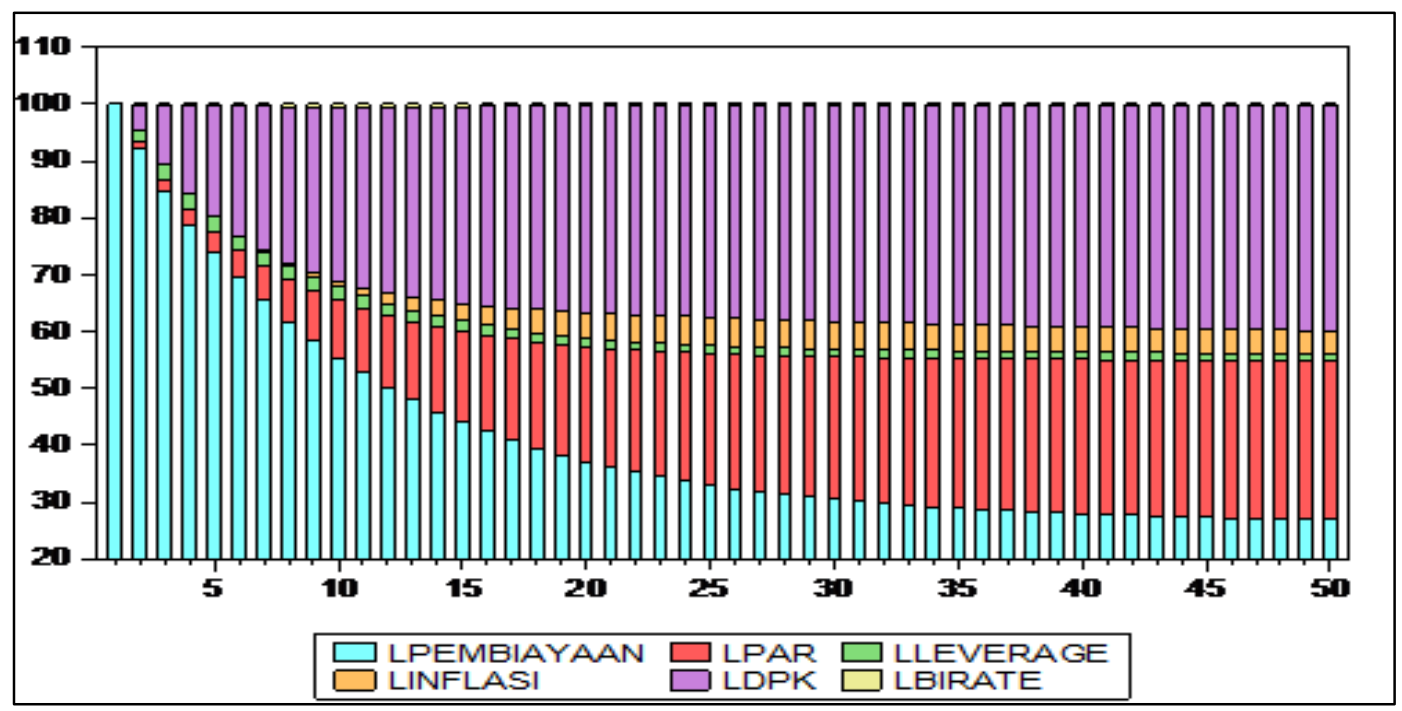

Gambar 16 FEVD Pembiayaan Perdagangan, hotel dan restoran BPRS

Pada bulan kedua menunjukkan bahwa peran pembiayaan PHR masih dominan dalam menjelaskan fluktuasi pembiayaan PHR itu sendiri, yakni sebesar 92,14\%. Sementara, DPK berada pada urutan kedua sebesar 4,58\%, selanjutnya diikuti oleh variabel Leverage sebesar $1,71 \%$, lalu variabel $\mathrm{PaR} 1,41 \%$, variabel $\mathrm{BI}$ rate sebesar $0,08 \%$, dan terakhir variabel Inflasi sebesar $0,05 \%$.

Kontribusi variabel DPK dari bulan ke bulan terus mengalami peningkatan dan memberikan kontribusi yang lebih besar terhadap pembiayaan PHR. Hal tersebut dapat ditunjukkan bahwa dari bulan kedua hingga bulan ke50, variabel DPK memberikan kontribusi terbesar kedua setelah pembiayaan PHR itu sendiri, yakni sebesar 4,5\% pada bulan ke-empat dan $39,5 \%$ pada bulan ke-50. Selanjutnya, PaR juga tampak semakin memengaruhi pembiayaan PHR dengan kontribusi yang terus meningkat terhadap pembiayaan PHR hingga periode ke-50, yakni sebesar $27,8 \%$. Variabel Inflasi juga menunjukkan tren peningkatan dalam hal kontribusi terhadap sektor PHR dimana pada bulan 50 kontribusi inflasi terhadap pembiayaan PHR sebesar 27,8. Sedangkan variabel $\mathrm{BI}$ rate cenderung stabil dalam hal kontribusi terhadap sektor PHR pada rentang 0,3\% sampai $0,4 \%$ dimana tepatnya pada bulan ke 33 hingga bulan ke 50 kontribusi variabel BI rate terhadap pembiayaan PHR berkisar $0,3 \%$ dan cenderung stabil. Untuk variabel Leverage menunjukkan kontribusi yang terus menurun hingga bulan ke-50. Dimana pada bulan ke 4 kontribusi variabel Leverage terhadap pembiayaan sektor PHR sebesar 2,7\% dan terus menurun sampai bulan ke 50 yang menyentuh angka $1,3 \%$.

Hasil FEVD ini menunjukkan kontribusi variabel yang diteliti terhadap keragaman pembiayaan PHR. Keragaman dalam pembiayaan PHR paling besar dipengaruhi oleh pembiayaan PHR itu sendiri, kemudian DPK, dan PaR. Kontribusi pembiayaan PHR dalam menjelaskan fluktuasi pembiayaan PHR itu sendiri semakin lama akan semakin menurun, namun penurunan tersebut akan digantikan dengan peningkatan kontribusi dari variabel lainnya. 


\section{KESIMPULAN DAN SARAN}

\section{Kesimpulan}

Berdasarkan penelitian yang telah dilakukan, maka dapat disimpulkan halhal sebagai berikut:

1. Pembiayaan sektor perdagangan, hotel dan restoran (PHR) pada BPRS selama periode tahun 2011 hingga tahun Juli 2016 mengalami peningkatan secara nominal, namun mengalami penurunan secara proporsional.

2. Hasil penelitian menunjukkan bahwa faktor yang signifikan memengaruhi pembiayaan PHR dalam jangka pendek adalah faktor DPK. Sedangkan untuk jangka panjang, faktor yang berpengaruh signifikan adalah $\mathrm{BI}$ rate, $\mathrm{DPK}, \mathrm{PaR}$ dan inflasi. Faktor yang tidak signifikan memengaruhi pembiayaan PHR pada jangka pendek maupun jangka panjang adalah Leverage.

3. Guncangan DPK, PaR dan Leverage direspon positif oleh pembiayaan perdagangan, hotel dan restoran, sedangkan untuk guncangan pada BI rate dan inflasi direspon secara negatif oleh pembiayaan sektor perdagangan, hotel dan restoran.

4. Faktor yang memiliki kontribusi paling besar terhadap keragaman pembiayaan sektor perdagangan, hotel dan restoran adalah variabel pembiayaan PHR itu sendiri, kemudian variabel DPK dan PaR.

\section{Saran}

1. BPRS harus lebih menggiatkan pengumpulan Dana Pihak Ketiga (DPK) sebagai instrumen untuk meningkatkan kuantitas pembiayaan yang diberikan, dikarenakan DPK signifikan memengaruhi pembiayaan sektor PHR pada jangka pendek dan panjang.
2. BPRS harus mampu menganalisis kondisi calon nasabah dan risiko pembiayaan yang mungkin terjadi serta melakukan controling dan evaluasi kinerja sehingga dapat mengurangi tingkat pembiayaan bermasalah. Tingkat $\mathrm{PaR}$ yang dimiliki BPRS di Indonesia sebesar 9\%, dimana berada di atas rentang standar yang ditetapkan oleh Bank Indonesia bahwa batas wajar rasio PaR sebesar 5\%. Tingginya pembiayaan bermasalah yang direpresentasi-kan oleh PaR akan berdampak pada berkurangnya kepercayaan masyarakat untuk menyimpan dananya pada BPRS.

3. Untuk penelitian selanjutnya disarankan menambahkan dan menggunakan variabel-variabel lainnya, seperti variabel makro lainnya dan indikator kinerja Camel.

\section{DAFTAR PUSTAKA}

Amiri MU, Kalangi JP, Walewangko EN. 2015. Pengaruh Sektor Perdagangan, Hotel, Restoran dan Sektor Jasa-Jasa terhadap PDRB kota Manado [Jurnal]. Jurnal Berkala Ilmiah Efisiensi. 15(4):78.

Anggraeni L, Puspitasari H, Ayyubi SE, Wiliasih R. 2013. Akses UMKM Terhadap Pembiayaan Mikro Syariah dan Dampaknya Terhadap Perkembangan Usaha : Kasus BMT Tadbiirul Ummah, Kabupaten Bogor [Jurnal]. Jurnal al-Muzaraah. 1(1):58.

Buchori A, Himawan B, Setijawan E, Rohmah N. 2003. Kajian Kinerja Industri BPRS di Indonesia [Jurnal]. Jakarta (ID): Buletin Ekonomi dan Perbankan. 
[BPS] Badan Pusat Statistik. 2006. Sensus Ekonomi. Jakarta (ID): Badan Pusat Statistik. - 2012. Statistik Hotel dan Akomodasi Lainnya. Jakarta (ID): Badan Pusat Statistik. . 2014. Statistik Restoran dan Rumah Makan. Jakarta (ID): Badan Pusat Statistika - 2015. Distribusi Persentase Produk Domestik Bruto Triwulanan Atas Dasar Harga Berlaku Menurut Lapangan Usaha. Jakarta (ID): Badan Pusat Statistik. . 2015. Klasifikasi Baku Lapangan Usaha. Jakarta (ID): Badan Pusat Statistika.

. 2015. Kontribusi Sektoral terhadap PDB dan Penyerapan Tenaga Kerja Tahun 2014. Jakarta (ID): Badan Pusat Statistik. . 2015. Laju Pertumbuhan PDB Triwulan Atas Harga Konstan
2000 Terhadap Triwulan Sebelumnya. Jakarta (ID): Badan Pusat Statistika.

Kara M. 2013. Kontribusi Pembiayaan Perbankan Syariah terhadap Pengembangan Usaha Mikro, Kecil dan Menengah [Jurnal]. Jurnal Ahkam. 13(2):316.

Kementerian Koperasi dan Usaha Kecil dan Menengah. 2011. Data Kredit Usaha Rakyat (KUR) per Mei 2011. Jakarta (ID): Kementerian Koperasi dan Usaha Kecil dan Menengah.

Kementrian Pariwisata. 2016. Perkembangan wisatawan nasional.

http:/www.kemenpar.go.id. [2017 Januari 25]

Supriyadi A. 2003. Sistem Pembiayaan Berdasarkan Prinsip Syariah. Jurnal Al-Mawarid 10:45. 